\title{
PROVIDING THE RIGHTS AND FREEDOMS OF INDIVIDUALS AND CREATING THE INTERNAL REVENUE CODE
}

$\mathrm{T}$ he point of view, in compliance with the socially-legal mechanism of protection of human and citizen rights, being the system of facilities and factors creating the necessary terms of respect of the rights and freedoms of man, that is created in modern legal systems, is widespread in scientific literature ${ }^{1}$. This mechanism contains social norms, legitimate activity of subjects of human and citizen rights, publicity, public opinion, guarantees (general, special, legal and organizational), procedures, responsibility and control. In addition, in L.A. Morozova's opinion, this mechanism must include facilities of stimulation of realization of the rights and freedoms of man and citizen, and creation conditions when envisaging the rights and freedom can really belong to the concrete man, used by him without some external obstacles ${ }^{2}$.

Thus, providing the rights and freedoms of individuals in the modern state, it is impossible to attain them simply by the acceptance of a new law (by improving the old one). The supporters of this point of view overestimate the role of law and underestimate the value of other factors that the realization of the rights and freedoms is related to, namely: material, financial, administrative and others. At the same time, the prevalence of this position (its support is declared by both researchers and ordinary citizen) emphasizing the presence of inherent sources of law plays an important role in the mechanism of protection of human and citizen rights in a modern society.

The source of law is followed by a national or international association as an external form of existence obligatorily protected by the state or social rules of behavior - norms of law.

The Republic of Belarus belongs to the group of legal systems where the centralized source of law - a normative legal act, has a qualifying value. Actually, the Republic of Belarus' system of law is the system of normative legal acts. To provide orientation in a great number of legal norms regulating public relations, systematization of legislation is used in modern national legal systems contained in different normative legal acts. In legal science, three basics forms thereof are distinguished - incorporation, consolidation and code creation.

Code creation, in Prof. I.N. Senyakin's opinion, is the most difficult and perfect form of systematization. It can be defined as preparation and acceptance of a new legal act - a code connecting native, both external and internal, processing of current legislation ${ }^{3}$. The results of code creation can be bases, positions, codes, etc. The adopted acts are independent sources of law. State organs and subjects realizing legally binding obligations must allude to them. Code creation is effected by authorized public organs periodically and when an objective necessity of associating normative material into one organic act appears. Code creation always carries an official character. Code creation is influenced by the norms of law (it differs, for example, from incorporation by the fact that the subjects carrying out code creation deal with normative legal acts). Code creation is directed at simplification of public relations adjustment as it assists forming clearer sources of law. 
A result of code creation is an organic act, in particular a code, which differs in whole by several advantages. A code is a collection of legal norms that groups norms of law and expounds them in the systematized and successive manner regulating certain aspects of public life.

From the legal point of view, the value of a code is also great. According to the Law of the Republic of Belarus on normative legal acts of the Republic of Belarus (part 6, Article 10) being in force in the Republic of Belarus, codes have a large legal force in relation to other laws ${ }^{4}$.

Scientific sources distinguish a few types of code creation. They are universal, branch-related and special. Universal code creation aims at the creation of normative legal acts uniting basic branches of legislation. Such code creation was made, for example, by the issue of the complete collection of laws of the Russian Empire. Branch code creation unites legal binding obligations with certain sectors or sub-sectors of legislation. Special code creation unites norms of certain legal institutes or a few legal institutes.

From the point of view of the subjects, realizing the requirements of legal norms, legislation which includes codes has a number of advantages. Thus from the point of view of access to knowledge about the requirements of legal rules, searching them in a code looks more comfortable than looking for them in numerous normative legal acts. Normative material in a code is systematized and subject to certain logic of exposition. For an individual, clear exposition of the norms of law in a code and also its stability, i.e. the protracted enough period of its existence without making alterations in maintenance, has a special value.

Systematized legislation determines quality of legal practice founded on it. The law applying practice of special public organs based on the codes differs, as it appears, in larger uniformity and predictability. Moreover, it is much easier for a citizen to contest the law applying acts based on the norms of one source of law. Accordingly, effectiveness of the indicated actions can be higher.

Legislation including a code allows to carry out an effective control over the activity of law applying organs to a greater extent.

Tax law creation code is a special type of code creation. It is an appropriate result of perfection of normative legal acts which regulate the sphere of taxation. The Internal
Revenue Code of the Republic of Belarus united in itself legal norms contained before in different normative legal acts regulating both concrete types of taxes and payments and procedure of their collection. Before the introduction General and Special Parts of the Internal Revenue Code of the Republic of Belarus, numerous laws regulating the indicated sphere operated in the territory of the Belarusian state, namely: the Law of the Republic of Belarus on state duty, the Law of the Republic of Belarus on income tax from natural persons, the Law of the Republic of Belarus on value added tax and other. Besides the indicated acts accepted by the Belarusian Parliament, the sphere of public relations related to the establishment and penalty of taxes and other state payments were also regulated by plenty of acts of President of the Republic of Belarus (by decrees and orders), the Government - decisions of the Council of Ministers of the Republic of Belarus, and other normative legal acts. The existence of a great number of sources of tax law certainly hampered the adjustment of public relations that took place in this connection, unfavorably affecting realization of tax norms and their application.

The system of tax law of the Belarusian state that began to be established from the forming of a sovereign republic differed in bulkiness and complications. Another characteristic feature thereof is permanent changeability. By the end of the 1990s, in the Republic of Belarus there was a tax law falling short of the necessities of time. Imperfection of tax laws became a serious obstacle for further development of tax and financial relations in the country. This exactly stipulated the necessity of tax law reform .

The Internal Revenue Code of the Republic of Belarus was developing for long enough time. As a result, a summary of legislative acts appeared in Belarus systematizing the norms of tax law. The Internal Revenue Code of the Republic of Belarus possesses all features of organic law. It drives a large number of tax norms to the integral system coordinating and grouping them into divisions and sections. It allows to use single principles of the application of rules of tax law, identical mechanisms of adjusting them in public relations.

General Part of the Internal Revenue Code of the Republic of Belarus was accepted on December, 192002 and entered into force as of January, 12004 . Special Part of the Internal Revenue Code of the Republic of Belarus was accepted by the Parliament of the Republic of Belarus on December, 
292009 and entered into force by January, 12010 . The Internal Revenue Code of the Republic of Belarus contains 9 divisions and 44 sectors that unite 331 interpretations. The norms of the General Part of the analyzable normative legal act determine public relations managed by the Internal Revenue Code, basic principles of taxation, participants of tax legal relationships, and also formulate the concept of tax obligation, a payer of tax, and object of taxation. General Part of the Internal Revenue Code of the Republic of Belarus also contains parts about methods of providing executions of tax obligations, fiscal accounting and control, the order of appeal against decisions of tax organs. Special Part of the Internal Revenue Code of the Republic of Belarus regulates separate types of taxes and collections (duties), determines their payers, objects of taxation, sets the rates of taxes and collections (duties), and the order of their calculation and payment.

The Internal Revenue Code of the Republic of Belarus contains both typical and untypical norms of law. Typical norms are legal rules being whole state-imperious dictates including in their structure a hypothesis, disposition and approval. The untypical norms of law determine bases of legal adjustment of public relations, their aims, tasks, principles, limits, directions, connected legal categories and concepts. Thus, for example, Article 21 of the Internal Revenue Code of the Republic of Belarus "The rights of payers" and Article 22 of the same normative legal act "The duties of payers" contain typical legal norms, and Article 4 of the Internal Revenue Code of the Republic of Belarus "Basic principles of taxation in the Republic of Belarus", or Article 6 of the adopted Code "Taxes, collections (duties)" - untypical rules, namely: norms-principles and norms-definitions.

The Internal Revenue Code of the Republic of Belarus also contains imperative and non-mandatory norms providing rights, obligations and forbidding rules as well as norms of material and judicial law. Norms of material law are the rules which regulate maintenance of public relations. Norms of judicial law regulate the procedural and organizational questions of realization of material norms, permission of judicial conflicts, protection of rights and legal interests of legal relationships participants.

Code creation in tax law largely influences a legal status of individuals in a tax sphere, i.e. their tax legal status.
A tax legal status as a branch of legal status of individuals contains such elements as law principles, legal capacity and capability, the rights, duties and responsibilities of a taxpayer.

The presence of the Internal Revenue Code of the Republic of Belarus means that under the legal status of personality in a tax sphere, a modern legislative base is brought in the Republic of Belarus. Meaningfulness of кодификации of norms of tax law shows up in a number of aspects. On the one hand, maintenance of norms of the Internal Revenue Code of the Republic Belarus proves purging this sphere from ideological and class dogmatism, transition from the command-prohibitive methods of regulation of a legal position of personality to permit establish and pursue any initiative and enterprise of bureaucratic centralism to reasonable autonomy and independence. On the other hand, the norms of the Internal Revenue Code of the Republic of Belarus, as it appears, prove that human rights, dignity of personality, humanism, democracy, and justice began to take to the first place in adjusting mutual tax relations between man and the State protecting them even more. At least this ensues from Article 2 of the Internal Revenue Code of the Republic of Belarus which defines qualifying basic principles of taxation in the Republic of Belarus, namely: legality, generality and equality.

The conduct of individuals (people and citizens) in the Republic of Belarus in the field of public relations related to taxation is, first of all, determined by the norms of the Constitution of the Republic of Belarus, including duties set by Article 52 of the Constitution of the Republic of Belarus, the essence of which requires to the observance of the norms of the Constitution and laws and respect national traditions. Under Article 56 of the Basic Law of the Republic of Belarus, citizens of the Republic of Belarus are under an obligation to take part in financing government spending by state tax, duties and other payments ${ }^{5}$.

Concrete taxpayers' rights and duties are determined in particular in Articles 21 and 22 of the Internal Revenue Code of the Republic of Belarus. Thus, taxpayers have the right to get from tax organs at the place of keeping an account free information about operation of taxes, collections (duties) and acts of tax law, and also about the rights and duties of taxpayers, tax organs and their public servants, to get written explanations to questions of application of acts of tax law, to present the interests in tax organs 
independently or through the representatives, to use tax deductions on the grounds and in order set by the tax law. A taxpayer is under an obligation to pay taxes collections (duties) set by the tax law, keep an account in a tax organ according to the terms and order set by the Internal Revenue Code, and register profit (charges) and other objects of taxation in accordance with the established procedure.

For non-fulfillment or improper implementation of the duties imposed on a taxpayer, they bear responsibility in accordance with legislative acts (part 5, Article 22 of the Internal Revenue Code of the Republic of Belarus).

Under part 3 of Article 21 of the Internal Revenue Code of the Republic of Belarus, the administrative and judicial protection of taxpayers' rights and legal interests is guaranteed in the order determined by the Internal Revenue Code and other acts of legislation. This norm has a substantial value for providing the rights and freedoms of individuals in a tax sphere. In accordance with part of 1 of Article 86 of the Internal Revenue Code of the Republic of Belarus, decisions of tax organs and actions (inaction) of their public servants can be appealed to a higher tax organ or higher public servant. Envisaging the indicated rights, the Internal Revenue Code of the Republic of Belarus does not include many norms regulating these rights, it is limited to only 4 Articles. Thus, a direct procedure and terms of appeal are regulated by Article 87 of the Internal Revenue Code and questions of consideration of complaints are regulated by Article 88. On the one hand, it is clear that questions of appeals of decisions of tax organs, for example, in the judicial order, are also regulated by the Articles of the Civil Procedure Code of the Republic of Belarus and the Economic Procedure Code of the Republic of Belarus. On the other hand, the adopted legislative acts do not take into account a specific nature of tax legal relationships and carry a general character. And it, in turn, as appears, draws certain vagueness into the algorithm of actions of a legal subject whose rights and legal interests will be infringed when he appeals decisions of tax organs.

Tax law code creation did not solve all the problems of tax law and the practice of tax norms realization related to it. Thus, still, next problems remain currently unresolved. Firstly, there is a great number of normative legal acts which regulate tax legal relationships. Certainly, tax law cannot be equated with criminal law, that is actually limited only to one normative legal act - the Criminal
Code of the Republic of Belarus. At the same time, tax law continues to embrace a large number of legal acts, namely: the laws accepted in accordance with the Internal Revenue Tax Code of the Republic of Belarus, regulative questions of taxations, acts of President of the Republic of Belarus (decrees and orders), international agreements and other, hardly necessary to estimate as positive. From the point of view of individual agreements, it is hardly necessary to estimate them as positive. From the point of view of individuals, such state of affairs hampers the use of tax norms if, in general, they are possible to be used at all. In fact, without special knowledge, the abilities to understand this volume of legal rules, observing them is not so easy. Tax and other state organs of the Republic of Belarus frequently assume the knowledge of law when establishing facts of offences. That is why a situation when a subject who does not know legal rules commits tax misconducts is absolutely common practice. Secondly, as it appears, many parts of the Internal Revenue Code of the Republic of Belarus need explanation. This generates a requirement to cement the norms of the Internal Revenue Code. It will be correct if it is done by the authorized agents of public organs, although they do it reluctantly. Thus, it is necessary to take into account that the right to authentic interpretation of norms of the Internal Revenue Code of the Republic of Belarus belongs to the organ that accepted it - the Belarusian Parliament of the Republic of Belarus. The official legal applying interpretation of analyzable normative legal act is provided by the Constitutional Court of the Republic of Belarus. Indicated organs not often do it (if they do it in general). Accordingly, other subjects begin to comment on tax law, both professionals and amateurs. A result can again not make a law-abiding legal subject happy.

To decide on the questions in a tax sphere, the Internal Revenue Code Tax is not sufficient. Development of economic relations of the society is needed. But there are other questions. Economic reforms, a change of the principles on adjusting this sphere of public relations must also be done. One of the priorities of the Belarusian state is forming a stable order of economic relations and normal functioning of managing subjects. This will assist in increasing good behavior of subjects in a tax sphere. Tax payments will be gathered when the subjects obliged to pay them carry out a profitable economic activity.

The fourth issue to be solved is work performed by law applying organs in the indicated sphere. The practice of 
this work proves that there are many defects in this area of public relations. Thus, violations of legal norms are taking place both from the side of law applying structures and from the side of the legal subjects obliged to observe the tax law. The amount of offences in a tax sphere is growing from year to year. Due to this, the tendency of increased tax crimes is a major problem in the Republic of Belarus. Thus, in the first quarter of 2015, the results provided for by the plan did not verify 806 cases of illegal entrepreneurial activity, that was twice more than in the analogical period last year. 763 offenders were brought to administrative court justice. The lump sum of fines made 1.5 milliard of Belarusian Rubles. 1256 natural persons got, of course, warnings of pursuing business without state registration. In all tax organs, an arrest was imposed on material values and profits to the amount of 25 milliard Rubles. 18.2 milliard Belarusian Rubles made up for the profit of the state ${ }^{6}$.

For the violation of tax law, the following measures of economic responsibility are set in Belarus, i.e. penalties applied to the subjects of management - legal entities and individual businessmen. For the violation of tax law, the Belarusian legislator also provided for the application of measures of disciplinary responsibility with regard to the leaders of legal entities and individual businessmen who can be subjected to administrative and уголовно-правовой responsibility. Уголовно-правовая responsibility is the most serious type of legal responsibility set by the legislation of the Republic of Belarus for the violation of tax law norms.

The necessity of perfection of the socially-legal mechanism of providing the rights and freedoms of individuals requires the Republic of Belarus to determine ways of further development of tax law of Belarus and practice of its application.

As it appears, the Republic of Belarus must take the following steps:

- the Tax law must be based on exceptionally legal principles of adjusting public relations and must be free of influence of other factors, first of all, political ones;

- systematic activity must be developed to achieve perfection of tax-legal norms;

- it is necessary to provide stability and sequence in tax practice. It could be made with the help of debates assisted by the corresponding organs (for example, by the Supreme Court of the Republic of Belarus);

- development of a protective mechanism against tax tyranny assumed by law applying organs in a tax sphere is necessary;

- it is necessary to provide a process of education of taxpayers forming tax discipline and tax culture.

\section{$\underline{\text { Abstract }}$}

Code creation is one of the directions taking place in the republics which were earlier included in the former Soviet Union State. Code creation is connected with legislation development. A code as an organic legal act has several advantages which make it an effective legal act. Developed legislation is one of the conditions of providing the rights and freedoms of individuals.

Legal adjusting of public relations is aimed at forming of such an order of public social connections in which state and social institutes are working effectively, the rights and freedoms of individuals are realized, their infringed rights and interests are defended. Legal adjusting is effected by means of rules of law that is systematized by certain methods. One of such methods is code creation. Code creation in the sphere of tax law is one of the backer-ups of the rights and individual freedoms in the state.

\section{BIBLIOGRAPHY}

1. Besuglov A.A., Belomestnyh L.L., Russian Constitutional Law, M., Isdatelstvo AEFP, 2004.

2. Matuzov N.I., Malko A.V. (eds.), Theory of the state and right: course of lectures, $2^{\text {nd }}, M$., Urist, 2002.

3. Morozova L.A., Problems of the modern Russian state system, M., 1998.

A.A. Besuglov, L.L. Belomestnyh, Russian Constitutional Law, M., Isdatelstvo AEFP, 2004, p. 364.

L.A. Morozova, Problems of the modern Russian state system, M., 1998, p. 167.

N.I. Matuzov, A.V. Malko (eds.), Theory of the state and right: course of lectures, $2^{\text {nd }}$, M., Urist, 2002, p. 423.

[Electronic resource]. Accessible at: http://www.yurist.by/o-normativnyh-pravovyh -aktah-respubliki-belarus.

[Electronic resource]. Accessible at: http://www.pravo.by/main.aspx?guid=14551.

The amount of illegal PB grew in Belarus [Electronic resource]. Accessible at: http://5min.by/news/v-belarusi-viroslo-kolichestvo-nelegal-nix-ip.html. 